\title{
Worker feedback technologies and combatting modern slavery in global supply chains: examining the effectiveness of remediation-oriented and due-diligence-oriented technologies in identifying and addressing forced labour and human trafficking
}

\section{LISA RENDE TAYLOR and ELENA SHIH}

Abstract: The global proliferation of mobile-phone-based technologies in countries producing goods for global export_-including SMS, smartphone apps, hotlines, polls, and other methods - offers exciting opportunities for collecting worker feedback to support corporate responsible sourcing. This seven-country study analysed how such technologies vary based on their fundamental relationships with workers and with businesses, and their commitments to workers and business, which leads to varying impacts on workers' lives. Due-diligence-oriented technology tools were found to help control risk in supply-chain hot spots, but rarely identified modern slavery due to gaining little trust from workers, and business clients not being ready to expose or address modern slavery. Empowerment-oriented worker feedback tools were found to regularly identify modern slavery, forced labour, and human trafficking and to assist exploited workers, but most had no connection to business's due diligence. Key ethical concerns were exposed as well, including the burden that some technology tools place on worker respondents, with insufficient benefits and safeguards to those vulnerable informant populations.

Keywords: Technology, responsible sourcing, modern slavery, forced labour, human trafficking. 


\section{INTRODUCTION}

\section{Scope of analysis of worker feedback and exchange technologies}

'Worker voice' has emerged as a recent, often technology-enabled, approach to responsible sourcing, with the potential to achieve two critical ends: first, the collection of more and better data for supply-chain due diligence and detection of labour risks; and, second, the empowerment of workers, to better hear their feedback and strengthen remediation accordingly. Recent critical reviews of supply-chain management strategies have noted the displacement of 'traditional' labour organising in finding and addressing labour abuses; thus, new developments in worker voice hold tremendous potential to reintroduce the role of workers, as opposed to a focus on business-driven due diligence alone, to improve workers' lives and treatment on and off the job.

A 2018 report on 'Transformative Technology for Migrant Workers' (Farbenblum et al. 2018) offers an overview of the landscape of different technology-enabled tools that aim to transform migrant work within global supply chains. Focussing most closely on what it refers to as 'worker empowerment' tools, it offers a typology that breaks down worker empowerment tools according to four possibilities: (1) those that enable workers to rate and review recruiters, employers, and other intermediaries; (2) those that facilitate migrant workers' access to justice; (3) those that provide migrant workers with responsive and tailored information; and (4) those that promote peer-topeer connections and collective organising among workers. While the report considers how digital tools enable businesses to engage with migrant workers (Part I), and for migrant workers to engaged one another (Part II), it does not analyse business reporting tools alongside worker empowerment tools. We undertake this task in light of the fact that many of these tools make universal claims to be technological interventions against modern-day slavery, and find it crucial to make analytical distinctions between them. Additionally, we strive to fill the empirical gap the report identified, by following up on its call for field-based studies. Our qualitative research into migrant sending and receiving countries in Southeast Asia, South Asia, South America, and North America offers a deeper dive on the implementation and effectiveness of some of these 'worker feedback technology' tools in practice - that is, technologies that collect digital information from workers with regard to some aspect of working conditions, typically via telephone or computer - and how they actually impact on workers' lives. 


\section{A human rights versus risk-management framework for analysis: new legislation around supply-chain accountability and action against trafficking and slavery}

In 2010, the California Transparency in Supply Chains Act was introduced as the first modern slavery legislation to arise, followed by the United Kingdom's Modern Slavery Act in 2015. Other state-driven efforts in France and Australia followed, as summarised in Table 1. These laws focussed efforts toward an increase in supply-chain transparency, sparking a shift in the labour rights/human trafficking space, from one in which anti-trafficking practitioners worked through the state and civil society alone, to one that imagined and discussed solutions by working with private sector businesses. Some corporations responded to these laws by aiming to identify the highest risk hot spots in their supply chain, facing the daunting task of narrowing down extended supply chains to map and investigate them, with hundreds or thousands of first-tier suppliers, and tens of thousands of higher-tier suppliers downstream. The expectation of follow-on responses from global corporations with actions to address labour abuses across extended supply chains was also, for the most part, uncharted territory.

Table 1. Excerpts from new laws calling for action to improve the lives of victims of trafficking and slavery, and also increase transparency.

\begin{tabular}{ll}
\hline Law & Excerpt \\
\hline California Transparency In & $\begin{array}{l}\text { Business has a role in '... provid[ing] consumers with } \\
\text { information regarding their efforts to eradicate slavery } \\
\text { and human trafficking from their supply chains, educate } \\
\text { consumers on how to purchase goods produced by companies } \\
\text { that responsibly manage their supply chains, and, thereby, }\end{array}$ \\
improve the lives of victims of slavery and human trafficking.' \\
The act also references slavery and trafficking as crimes that \\
strip individuals of their dignity and notes, 'Business has a \\
role to play in tackling these crimes'(Explanatory Notes 2015). \\
The requirement of corporations' Board-level sign-off on \\
annual modern slavery statements ensures that modern slavery \\
is raised at senior leadership levels. \\
The Loi relative au devoir de vigilance des sociétés mères et \\
des entreprises donneuses d'ordre (2017) requires companies \\
to establish and effectively implement due diligence measures \\
to identify and prevent human rights violations and \\
environmental damages in connection with their operations, \\
with stricter penalties than the US and UK laws (Brabant \& \\
Savourey 2017). \\
The bill similarly states the desired outcome of the new law as \\
being '... increas[ing] business awareness of modern slavery, \\
reduc[ing] modern slavery risks in Australian goods and \\
services, and driv[ing] a business 'race to the top' to improve \\
workplace standards and practices'.
\end{tabular}


These laws have had far-reaching, though uneven, consequences, and legal scholars have yet to fully research their implementation. Our analysis approaches these laws through a human rights, rather than a risk-management framework, since it is clear from the new laws that there is an expectation on companies to act to improve working conditions, and the lives of victims of slavery and trafficking. A risk assessment framework is often initially applied by companies, prioritising the identification and mitigation of risk to the company, typically resulting in alternative sourcing, or a 'cut-and-run' approach. However, risk assessment alone, often through an auditcompliance approach (the private sector's main tool for assessing risk, from health and safety to environmental sustainability) often does not involve making additional efforts to contribute to remediation once labour violations are known. Significantly, a business's assessment of risk may not include assessment of the human rights consequences of actions to mitigate risk, as the spirit of these laws would require. For example, the consequences of cutting a supplier to protect the company from risk in its supply chain could lead to workers losing their jobs and being deported while still being indebted to their job recruiter. Thus, in recognition of the fact that reductions in risk from due diligence decisions have the potential to increase risk to the welfare of workers, a human rights analytical framework drives our investigation of the effectiveness of worker feedback tools in identifying, reducing, and/or eliminating forced labour and human trafficking.

\section{The challenge of extensive global supply chains}

Supply chains dominate global trade, with production of goods and service provision spanning continents, and workforce populations representing a diverse mix of nationalities, languages, ethnicities, and skills. This can take place globally, or within a single country or facility alone. Greater division of production in supply chains is fuelled by a number of factors, including low-cost and abundant labour, improved infrastructure and communications, relatively cheap and accessible land, and attractiveness of the regulatory and business-enabling environment.

Efforts to improve supply-chain visibility and sustainability can vary tremendously. To date, business efforts by global brands and retailers to better control their supply chain have focussed largely on the top export-tier suppliers - that is, those that produce and export goods, but which may have chains of processors, producers, and aggregators supplying them with various raw materials. In many cases, the export-tier production facilities are regularly audited by the facility's customers, resulting in a tremendous overlap of effort and sometimes with conflicting requirements, depending on the audit and code of conduct requirements of different American, European, and other buyers. This has led to growing interest among globally responsible buyers to 
align requirements and consolidate audit findings to avoid redundancy, time, and cost to the supplier, and general audit fatigue. Individual business requirements/needs and legal concerns, however, present significant obstacles to these harmonisation efforts.

Additionally, audits - whether announced or unannounced, in-house or third party - are only as good as the auditors themselves, and skill sets and rigour vary. Suppliers have become very well versed in the audit compliance process too, and know roughly when 'unannounced' visits will be taking place and the extent to which workers may be engaged in the process, if at all. Workers in Southeast Asia often report some degree of coaching and know what is expected of them by their bosses during an audit visit. Follow-up actions often rely on self-reporting by the supplier. Social audits have therefore become more common in an attempt to solicit more feedback directly from workers. These are an attempt at improvement over traditional audits, but are still generally viewed as not being as effective at uncovering more hidden and serious labour abuses - such as forced labour and trafficking in persons - as global brands and retailers had hoped. Gaining the trust of workers and uncovering very sensitive hidden information in a very short time period by an unknown party is simply difficult to achieve, and false positives can arise. Independent worker feedback channels by non-governmental organisations (NGOs), trade unions, and boutique tech firms, and tools to gather more information from workers, are thus on the rise, but still not widely available in many parts of the globe. And with new actors and technology now allowing more direct engagement with workers, concerns are fuelled about risks of reprisals to workers, data privacy, duty-bearer responsibilities, remedy, and overall ethical handling of worker feedback.

The prospect of monitoring supply chains beyond the export-level tier and ensuring that facilities have good working conditions, and that supplier codes of conduct are being upheld, can be daunting for most responsible sourcing teams. The number of suppliers operating at the second and third tiers and beyond multiplies significantly, and in many cases these businesses receive less scrutiny from global buyers, and receive fewer visits and audits. Labour risks may also increase with greater business informality, which often occurs upstream in multi-tiered supply chains. The perceived level of supply-chain risk and thus supply-chain prioritisation will be impacted by numerous factors, including the nature of the business/industry, the depth of the supply chain, the geography, extent of aggregation, capacity of the business, impact of seasonality, and workforce demographics.

Only a very small percentage of businesses in global supply chains are therefore audited. The majority of extended supply chains, further upstream beyond the exportlevel tier, are often unmapped - or, if mapping has taken place, the resources to audit them are simply not in place. This leaves global buyers and retailers to push their codes of conduct down the supply chain, and rely on their first-tier suppliers to ensure 
that compliance flows throughout the sourcing process. Thus, there is a growing interest on the part of global buyers in new ways to harness information on labour risks in their extended supply chain.

\section{The (re)emergence of 'worker voice': relationships with workers amidst due diligence priorities}

Threats to worker welfare and power in dispersed, extended supply chains have been a challenge to both the worker rights and the anti-trafficking communities. They are joined in their concern regarding labour exploitation due to the intrinsic risks that come from, first, increased use in making products in global supply chains of foreign or migrant workers - who are not allowed to organise, cannot speak the local language or realise their rights, and/or who suffer discrimination —or, otherwise easily oppressed or marginalised workers; and, second, the nature of extended supply chains - branching out to small and remote farms and plants where collective bargaining and action are challenged, where auditing hardly ever occurs, and where there is no civil society presence, essentially, invisible workers in the millions whose welfare is not easy to know. Worker rights and labour organising groups have worked directly with workers for hundreds of years, aiming to empower workers and drive responses from management through collective action and collective bargaining. Anti-trafficking organisations developed specialisations over the past two decades working with some of the most exploited workers in the world, providing protection and support to exploited workers as well as outreach and empowerment through hotlines, awareness raising, direct assistance, and more indirectly through policy advocacy and systems capacity building (often with governments).

Due diligence actors, particularly audit firms seeking to answer to the rising corporate demand to understand where to find labour risks, came to realise what has been a long-standing reality for labour advocates and organisers: in order to expose the reality of working conditions and abuses, workers need voice. Furthermore, only a partial picture can be derived from that which is reported by the supplier business (the employers). However, audits, at this point nearly two decades ago, were mostly based on suppliers' self-assessment and self-reporting - for example, the Sedex-related SMETA (Sedex Members Ethical Trade Audit) four-pillar audit-coupled with auditors visiting worksites and working with the supplier's management to collect information and review documents. Most social audits continue in this way today, seldom collecting data from workers. When they do, it is a practice rife with ethical and security issues for workers, not to mention practical interpretation and logistical challenges (Rende Taylor \& Latonero 2018). One report by Verité, as part of a project with The Gap, summarised the issue: 
Worker engagement has been a prominent topic in the realm of corporate social responsibility (CSR) in recent years. Various approaches have been explored by multinational brands in seeking worker feedback via different forms of engagement activities. However, these types of worker engagement programs are often treated as a separate activity which lack a systematic connection with other CSR programs. When closely examined, the designs of the programs are usually brand-centered and heavily oriented towards supply chain risk management. Workers' interests are often either overlooked or marginalised (Verité 2018).

Auditors and due diligence solution providers began to see the potential for enhancing their own efforts when it became clearer that many workers in factories, on farms, and even on fishing boats did, indeed, have mobile phones. Technologies could then be designed to reach large numbers, to ask questions, and gain data for due diligence and supply-chain triaging. However, in general, no meaningful relationship existed between workers and auditors or any other agencies engaged in due diligence.

By 2016, it became apparent to many programmers and donors alike that mobile phones were nearly ubiquitous in many modern slavery 'hot spots' of the world. Workers used mobile phones, and they were useful in being able to hear from workers in countries where collective bargaining and unionisation were illegal or suppressed. This came as no surprise to the anti-trafficking community, who were starting to mix in the corporate responsibility space, since anti-trafficking organisations had been running hotline and case-management programmes to directly support workers, vulnerable populations, and victims in most regions of the world for over a decade. By 2017, landmark conferences such as the Wilton Park ${ }^{1}$ conference in London in June 2017, entitled The Role of Digital Technology in Tackling Modern Slavery, were making direct connections between technology and anti-trafficking objectives, noting:

Smartphone apps and technology solutions can empower vulnerable workers to provide direct feedback on their working conditions and access to trusted information. This helps to reduce risks when seeking employment and assists businesses to increase transparency through their supply chain.

Smartphone apps rely on network connectivity, but many civil society organisations on the front line of tackling modern slavery often lack the most basic equipment and training. Without laptops, smartphones, and online case management systems and awareness of resources they will always lag far behind the criminals.

Interestingly, the Wilton Park discussion notes go on to suggest that technology providers should work to better understand and support anti-slavery organisations, making the assumption that the two are different and that most anti-trafficking organisations lack the capacity to develop their own technology and even 'lack the most

\footnotetext{
${ }^{1}$ https://www.wiltonpark.org.uk/wp-content/uploads/WP1546-Report.pdf
} 
basic equipment and training'. At this point, it is clear that three distinct groups have emerged from this historical perspective that have an interest in hearing from and/or helping vulnerable workers, but that are significantly different in their mission and baseline relationship with workers:

1. Due diligence technology providers, mostly for-profit businesses, staffed primarily by technology project managers and developers, and aiming to meet the new demand from businesses for ways to triage their supply chains, map them, and understand risk better;

2. Anti-trafficking and labour rights organisations, mostly non-profit organisations, which had been in touch and working with exploited migrant workers from the trafficking/human rights/crime angle, aiming to identify victims, protect the rights of trafficked persons, provide client-centred case management and services, and bring their abusers to justice; and

3. Worker organisations and trade unions which were also working with workers on collective bargaining and worker organising, but which have limited opportunities in some situations to do worker organising-for example, in countries where the law limits freedom of association, in supply chains where workers can be very geographically dispersed, or where local labour union members are reluctant to include and assist foreign migrant workers.

Acknowledgement of the different starting points, missions, and relationships with workers of these three distinct groups makes unsurprising the fact that these groups have distinctly different goals and theories of change for the worker-centred technologies with which they are affiliated.

\section{METHODOLOGY}

\section{Summary of methodology}

Qualitative research across global supply chains requires ethical considerations of the different power relationships between stakeholders. Our research design aimed to develop case studies of the technology-enabled worker feedback programmes listed in Table 2. This project interviewed investors, donors, tech companies, multinational corporations, subcontractors and suppliers, migrant recruiters in countries of origin, worker centres, migrant worker NGOs, and workers. We took seriously relationships of power between workers and employers, with the understanding that workers are also agents capable of expressing their consent and dissent. Our methods focussed on gaining multi-stakeholder views on the value and utility of technology-enabled worker 
Table 2. Field sites visited and technology tools studied, by location of deployment and primary objective (due diligence or remediation).

\begin{tabular}{|c|c|c|c|c|c|c|}
\hline \multirow[t]{2}{*}{ Country } & \multirow[t]{2}{*}{ Tool } & \multirow[t]{2}{*}{ Developer } & \multicolumn{2}{|c|}{$\begin{array}{l}\text { Location of } \\
\text { deployment }\end{array}$} & \multicolumn{2}{|c|}{$\begin{array}{l}\text { Primary objective of the } \\
\text { technology tool }\end{array}$} \\
\hline & & & origin & destination & $\begin{array}{c}\text { due } \\
\text { diligence }\end{array}$ & remediation \\
\hline \multirow[t]{6}{*}{ Bangladesh } & Laborlink & ELEVATE & & $\checkmark$ & $\checkmark$ & \\
\hline & Symphony & LaborVoices & & $\checkmark$ & $\checkmark$ & \\
\hline & Bangladesh & Laborlink + & & $\checkmark$ & $\checkmark$ & $\checkmark$ \\
\hline & Alliance & Phulki's Amader & & & & \\
\hline & & Kotha helpline + & & & & \\
\hline & & Cahn Group & & & & \\
\hline \multirow[t]{5}{*}{ Malaysia } & Laborlink & ELEVATE & & $\checkmark$ & $\checkmark$ & \\
\hline & Muglan & Muglan247 & $\checkmark$ & $\checkmark$ & & $\checkmark$ \\
\hline & Recruitment & International & & $\checkmark$ & & $\checkmark$ \\
\hline & Monitor & Trade Union & & & & \\
\hline & & Confederation & & & & \\
\hline \multirow[t]{5}{*}{ Mexico } & Contratados & Centro de los & $\checkmark$ & $\checkmark$ & & $\checkmark$ \\
\hline & & Derechos del & & & & \\
\hline & & Migrante & & & & \\
\hline & RADAR & ProDesc & $\checkmark$ & & & $\checkmark$ \\
\hline & Database & & & & & \\
\hline Myanmar & Golden Dreams & Issara Institute & $\checkmark$ & $\checkmark$ & $\checkmark$ & $\checkmark$ \\
\hline \multirow[t]{2}{*}{ Nepal } & Shuvayatra & Asia Foundation & $\checkmark$ & $\checkmark$ & & $\checkmark$ \\
\hline & Worker Connect & Caravan Studios & & $\checkmark$ & & $\checkmark$ \\
\hline Thailand & Golden Dreams & Issara Institute & $\checkmark$ & $\checkmark$ & $\checkmark$ & $\checkmark$ \\
\hline
\end{tabular}

feedback tools, and then carrying out field-based research to study how these tools were deployed on the ground and used by workers, businesses, and others (such as worker rights groups). Following this, preliminary results were presented to stakeholders to gain their feedback. Analysis was limited to worker feedback technology tools, meaning only websites and applications that collected digital data from workers with regard to their working conditions; analysis of other worker-oriented tools that do not collect feedback from workers was not included.

\section{Stakeholder interviews}

Semi-structured interviews were conducted either in person or over teleconference with global buyers, development donors, and technology creators prior to conducting fieldwork.

\section{Fieldwork}

At each site visit, the research team conducted semi-structured interviews with the teams or organisations managing the technology product, as well as focus groups with workers at each site where technology is deployed. Interviews were also conducted 
with local civil society organisations and trade unions familiar with the situation of workers and jobseekers, as well as with employer/supplier businesses and recruitment agencies. In source countries, interviews with jobseekers, prospective migrants, and returned migrants were facilitated by local organisations and trade unions.

In order to recruit respondent workers or jobseekers who use the technology tool of interest, we asked the NGO or tech company administering the tool to inform all workers of an opportunity to participate in the study. Employers did not participate in the solicitation so that workers understood that their participation was not related to their employment. Workers participated in focus groups of approximately five to ten workers. We did not ask workers to participate in one-to-one interviews to reduce the risk that any negative feedback about the workplace or about the application could result in being possibly identified by employers. In some countries, such as Malaysia, local civil society groups invited the team to meet with migrant worker populations that included workers familiar with some of the technologies of interest, coupled with workers who were not familiar with any of the technologies. These interviews were valuable in understanding the broader challenges faced by technology-based programmes to reach and be relevant to certain target groups.

\section{CASE STUDIES AND GEOGRAPHIC CONTEXT}

\section{Outmigration from Myanmar, Mexico, and Nepal}

The technology tools studied in this research were deployed in a range of environments - some in specific factories or workplaces, some focussing on national industries, and some operating across the origin and destination countries of migrant workers. The international labour migration channels in this study included outmigration from the origin countries of Myanmar, Mexico, and Nepal. All of the technology tools deployed in origin countries were jobseeker and worker empowerment, and remediationoriented platforms; only one of these also contributed to due diligence regarding supply-chain risks related to exploitative labour recruitment.

The research team was able to visit four destination countries as well, namely Bangladesh (domestic migration), Malaysia, Thailand, and the United States. ${ }^{2}$ Technology tools in destination countries included both due diligence tools deployed in select workplaces and industries, as well as worker empowerment tools targetting

${ }^{2}$ The Centro de los Derechos del Migrante's Contratados platform and ProDesc's RADAR legal database aim to assist Mexican migrants to the United States, as well as internal Mexican migrants. Mexico, however, is not listed as a destination country because the focus of these technologies are cases of cross-border migration. 
particular migrant worker populations. Case studies of these localities will be presented prior to the key findings and recommendations, to provide context regarding the situation of jobseekers and migrant workers as they move into work in global supply chains.

\section{Migration patterns}

Jobseekers from Myanmar and Nepal migrate to a number of different countries in the Gulf States and countries in Southeast Asia, such as Thailand, Malaysia, and Singapore, and beyond. Burmese migrants also migrate to Japan and South Korea in East Asia. Thailand is the most popular destination country for Burmese migrant workers, with close to 70 per cent of all Burmese migrants currently living in Thailand; the second most popular destination country is Malaysia. Malaysia is the most popular destination country for Nepalese migrant workers, followed by the Gulf States of Qatar, Saudi Arabia, the United Arab Emirates, and Kuwait. Nepalese workers also migrate to countries like Poland, Jordan, and Japan, into the construction, garment, services, and electronics sectors. For Mexican labour migrants, the majority migrate to the United States for work using both a wide range of formal guest worker visas and informal migration channels. ${ }^{3}$

\section{Information sources for migration}

Jobseekers in all three origin countries receive information about labour migration in a number of ways, with person-to-person information exchange - with migrants and others - being the most common and trusted way in which jobseekers, especially in rural parts of the country, learn about migration pathways and job opportunities abroad. In all three origin countries, relatives and friends in villages who have migrated or are about to migrate are key primary sources of information-particularly seasoned migrants and returnees, who have first-hand, updated information based on their own personal experiences. Community-level brokers are not omnipresent, but where they are located, they are often key sources of information when relatives and friends are not present, proactively operating to recruit workers to go abroad (often for a price).

\section{Recruitment agencies}

Recently, recruitment agencies in Myanmar — which are all based in the former capital of Yangon-have also started employing registered sub-agents to spread information about their job offerings at the community level. In addition, there is a small but

\footnotetext{
${ }^{3}$ International Labour Organization Regions and Countries, available at https://www.ilo.org/global/ regions/lang--en/index.htm. Migration Policy Institute, Countries, available at https://www.migrationpolicy. org/regions/
} 
increasing number of community-based and civil society organisations that are working as a coordinated network to essentially displace exploitative, informal brokers and provide specific information about more ethical recruitment pathways, and jobs available through them, to jobseekers in Myanmar (Rende Taylor \& Ei Ei Chaw 2018). However, the great majority of jobseekers get connected to recruitment agencies holding overseas job opportunities through informal, freelance brokers who often extract high fees from jobseekers who are not aware of market costs and job options.

In Nepal, manpower agencies work with the media, civil society, community leaders, and government to advertise jobs. In Mexico, given bureaucratic challenges to accessing US guest worker visas, migrants rely on formally registered and informal recruiters to identify work opportunities. Many Malaysian, Thai, and US employers use agents and recruiters in their countries to liaise with recruiters in the origin countries to find and hire new workers; essentially, many employers often do not want to deal directly with actors in origin countries and so outsource the recruitment process to a risky chain of agents that they are often not fully aware of.

\section{Technology to empower jobseekers}

Burmese, Mexican, and Nepalese jobseekers are increasingly using technology to access information about migration, particularly given the risks of migration through informal brokers, which are becoming increasing well known and discussed over social media. Social media, in particular the widespread use of Facebook, has become a commonly used source of information, with 18 million registered Myanmar Facebook users as of January $2017^{4}$ (34 per cent of total population of 53 million), 9.5 million registered Nepalese Facebook users as of April 2018 33 per cent of total population of 29 million), and 54 million registered Mexican Facebook users as of $2018^{6}$ (42 per cent of total population of 129 million).

In all origin countries included in this study, there are a number of pages and groups on Facebook that provide information about migration and job opportunities. Some are run by recruitment agencies, some by brokers, some by civil society organisations, and some by workers who have already migrated and are now willing to share their own experiences with prospective migrants. Technology platforms provide an opportunity for workers to exchange information on recruitment, to share safe migration information and job opportunities. In response, several key providers have emerged in order to address misinformation and information asymmetries with regard to international labour migration, including Contratados in Mexico (created by the

\footnotetext{
${ }^{4} \mathrm{https} / / /$ www.statista.com/statistics/193056/facebook-user-numbers-in-asian-countries/ ${ }^{5} \mathrm{https}$ //www.thesocialmediatoday.com/social-media-users-facebooktwitterinstagram-in-nepal-2018/ ${ }^{6}$ https://www.statista.com/statistics/282326/number-of-facebook-users-in-mexico/
} 
Centro de los Derechos del Migrante (CDM)), Shuvayatra in Nepal (created by the Asia Foundation), and Golden Dreams in Myanmar (created by the Issara Institute).

Contratados and Golden Dreams are 'Yelp-like' platforms, allowing workers to rate and review employers, recruiters, and service providers, as well as access a range of information related to labour rights and processes and costs of migration. Shuvayatra does not having ratings and reviews, but it does have a range of information and resources for jobseekers and migrant workers, including informational radio call-in shows, connections to traditional Nepalese music channels, and contact information for embassies and other resources at the destination.

\section{Labour conditions in Bangladesh, Malaysia, Thailand, the Gulf States, and the United States}

\section{Supply chains and exports}

Migrant workers in the destination countries covered by the study work in a number of low-skilled industries, such as fishing, agriculture, construction, manufacturing, electronics, and domestic service. In Bangladesh, domestic (Bangladeshi) workers are a key part of the ready-made garment industry, which constitutes more than 80 per cent of Bangladesh's annual exports. ${ }^{7}$ In Malaysia, migrant workers are particularly crucial to the electronics and electrical machinery industry, which makes up around 40 per cent of Malaysia's exports; they are also a significant presence in the workforce of industries such as construction, palm oil, and manufacturing. ${ }^{8}$ Thailand's position as one of the top global exporters of seafood is heavily reliant on the presence of migrant workers in the fishing and seafood industries. In addition, migrant workers are also key components of the workforce in other low-skilled industries, such as agriculture, electronics, construction, apparel and footwear, manufacturing, and domestic work. Construction and domestic work are also the two most common industries for migrant workers in the Gulf States. And in the United States, agriculture, cleaning and maintenance services, and construction have the three largest shares of low-skilled migrant workers (Porter 2017).

\section{Local legal and policy frameworks and enforcement}

In its efforts to identify and combat human trafficking and forced labour, Thailand has established an anti-trafficking task force composed of law enforcement officers, social workers, and NGOs. In addition, the government has also conducted training for labour inspectors on forced labour. However, the country continues to have high

\footnotetext{
${ }^{7} \mathrm{http}: / /$ www.worldstopexports.com/bangladeshs-top-10-exports/

${ }^{8} \mathrm{http}: / /$ www.worldstopexports.com/malaysias-top-10-exports/
} 
numbers of unidentified victims, and to misidentify victims of trafficking or forced labour. For instance, some victims of trafficking are misidentified as illegal workers who are criminalised, detained, tried, and consequently deported (State Department 2018a). In the case of Malaysia, the country has amended the foreign worker levy and Private Employment Agency Act, and it improved the implementation of the amendment regulations of the anti-trafficking law, which allows survivors to work and move freely, receive a mental health evaluation, and obtain medical screening (State Department 2018b). However, in reality, freedom of movement is limited and victims are required to be accompanied by a chaperone. In addition, similar to Thailand, the Malaysian government sometimes fails to identify potential victims of trafficking, leading to victims being detained, deported, or charged with immigration offences.

Working conditions in the ready-made garment sector in Bangladesh came to international attention in 2013 after the collapse of a factory-Rana Plaza-killed more than 1,100 workers who were part of the global supply chains of a number of well-known multinational apparel brands. As a response to the disaster and to improve safety and working conditions in factories in future, European companies such as H\&M, Primark, and others created the Bangladesh Accord, while North American companies such as Walmart, The Gap, and others created the Bangladesh Alliance. While there were key differences between the two-for example, the Accord had a more robust and legally binding structure than the Alliance, and was also more vocal about the role of workers by including trade unions in its work, which the Alliance did notboth did factory inspections and oversaw remediation for workers. For factories not covered by the Accord or Alliance, the Bangladeshi government set up a third initiative called the National Tripartite Plan for Fire and Structural Integrity, which was backed by the International Labour Organization (ILO), among other groups (Yee 2015).

Both the Alliance and the Accord were meant to end in 2018, five years after they were signed, with the responsibility for continued inspections to be transferred to a body under the Bangladesh government. The Alliance followed through with that original plan, discontinuing operations in Bangladesh in 2018. The Accord, on the other hand, was initially renewed for three more years in 2018 - extending its mandate to 2021 - based on the observations that serious issues continued to exist in a number of Accord factories, and that the Bangladesh government was not ready to take over all responsibilities. This extension, however, has repeatedly been challenged in courts in Bangladesh after the government decided that it was ready to take over all inspections and did not require a foreign-mandated body to continue operations in the country. While the Accord has received temporary extensions a few times since the initial court case, with the most recent one being a two-month extension granted in February 2019, most commentators believe that the efficacy of the Accord has been seriously hampered by restrictions placed on it by the government. 
Labour conditions, safeguards for workers, and responses of employers

The bilateral relationship between the United States and Mexico is characterised by the porous exchange of goods and movement of people across a vast geographically contiguous physical border. The United States has relied heavily on Mexican migrant labour, primarily in the agriculture industry, instituting guest worker visas as early as the 1942 Bracero Program, and has eagerly supported the regularisation of free trade through the North American Free Trade Agreement (NAFTA). However, despite the availability of formal legal migration channels, many migrants seek undocumented migration pathways, and often find themselves in situations of labour exploitation. As is true with workers throughout Asia and the Gulf States, undocumented migrants are often unwilling or unable to access support for fear of deportation, while migrants on guest worker visas are fearful of employer responses because their visas are strictly tied to their employer (CDM 2011).

Migrant workers in Malaysia face a range of risks, including being cheated, experiencing debt-bondage, having their documents seized by employers or recruiters, and having their wages withheld for many months. Likewise, migrant workers in Thailand are exposed to these risk and abuses, as well as labour exploitation through involuntarily long working hours and low wages that violate local and international laws. Migrant workers in both countries face difficulties in escaping from these situations because their legal status and work permit are attached to the employer. The risk of becoming illegal as the result of escaping an exploitative situation without documents in-hand is that workers can be taken to detention centres and face deportation, and become more vulnerable to being re-exploited.

When workers face these kinds of issues and abuses, they can seek for help from locally based organisations that provide guidance on how to access protection, remediation, and other services. Some may provide legal aid and rescue services, and help facilitate returns home without government intervention, such as the General Federation of Nepalese Trade Unions (GEFONT), the Pravasi Nepali Coordination Committee (PNCC), and Muglan, which are Nepalese-run groups assisting Nepalese in Malaysia, and the Migrant Worker Rights Network (MWRN) and the Confederation of Trade Unions Myanmar (CTUM), which are Burmese-run groups assisting Burmese in Thailand. Others may drive raid-rescue operations in collaboration with local law enforcement, though this often leads to the incarceration (or involuntary 'sheltering') of victims, such as through the Malaysian-run NGO Tenaganita in Malaysia, and Thai-run Labour Rights Promotion Network (LPN) in Thailand. Several NGOs and trade unions facilitate the communication of grievances between workers and employers to drive remediation; in Malaysia and Thailand, there are issues of local trade unions not being willing to, or not having the capacity to, provide assistance to non-national (that is, foreign) workers, thus requiring the intervention of 
source-side trade union representatives such as GEFONT and CTUM in destination countries. In the Gulf States, it is a massive challenge that essentially no civil society or local trade union support is available to foreign migrant workers.

The complexity of grievance mechanisms, remediation processes, and contracting of international labour recruitment can also pose serious challenges for workers to access justice or remediation. In Malaysia and Thailand, for example, workers may have two contracts drafted under two different jurisdictions that may conflict. In the case of Thailand, migrant workers hired through the government-to-government channel have contracts issued by the source-country government via recruitment agencies but signed by employers, and then also a second employment contract with the employer in the destination country, drafted with reference to destination-country national laws alone that is not supposed to, but can sometimes, conflict with the first contract.

In Bangladesh, important strides have been made on worker safety in the readymade garment sector under the Accord and the Alliance. A large number of factories covered by the two initiatives have installed fire doors, added fire extinguishers and sprinkler systems, improved electrical wiring, instituted fire-safety training programmes, and made structural upgrades that protect workers' lives. Both initiatives also operated independent hotlines for workers to raise grievances, which included mechanisms to follow up with remediation; the Alliance hotline has now been spun off and rebranded as the Amader Kotha helpline administered by a local non-profit organisation, Phulki. But, as staff of the Accord themselves acknowledged in 2018, 'major life-threatening safety concerns remain outstanding in too many factories and need to be fixed urgently' (Barrett et al. 2018). The laudable progress on safety has also widened the bifurcation of the industry. An elite segment of suppliers can afford to make improvements and continue to enjoy relationships with international brands and retailers. Much of the rest of the industry, however, either cannot or will not make expenditures to enhance safety and, as a result, workers in this segment remain at risk. Even some of the factories that have seen improvements are in danger of backsliding, as the foreign initiatives conclude and all oversight responsibility reverts to the Bangladeshi government, which continues to move very slowly on safety. This is also reflected in the safety standards in factories not covered under the jurisdiction of the Accord or the Alliance, which made little or no progress in addressing problems over the past five years. ${ }^{9}$

Worker protests in late 2018 and early 2019 around the raising of the minimum wage demonstrate that workers still remain highly vulnerable in the policy environment in Bangladesh, and reprisals are rampant. Nearly 11,000 workers have been

\footnotetext{
${ }^{9}$ Interview with due diligence technology developer (October 2018).
} 
dismissed in the aftermath of the protests, and many suppliers are cooperating among themselves to blacklist workers and prevent them from acquiring jobs. Worker unions are hard to register due to the bureaucratic nature of the process, and many of the existing trade union leaders have been targetted by the police in the aftermath of the protests. ${ }^{10}$ While some suppliers engage with workers and trade unions in good faith, most do not want to engage with them, especially as the Accord and the Alliance wind down and global buyer leverage decreases. ${ }^{11}$

\section{RESULTS}

The key findings of the research are divided into two categories: key findings regarding the effectiveness and accuracy of the technology tools at identifying human trafficking and forced labour, and key findings regarding the effectiveness and accuracy of the technology tools at addressing human trafficking and forced labour.

\section{Effectiveness and accuracy of the technology tools at identifying human trafficking and forced labour}

\section{Key Finding 1.1. Tools that aim to uncover human trafficking and forced labour do; tools that do not necessarily want to uncover human trafficking and forced labour do not.}

Whether or not a worker feedback technology tool effectively identified trafficking and forced labour risks depended largely on who drove its design and implementation, and what they designed the tool to find. Drawing from interviews with technology developers, where they were invited to discuss their 'origin stories' and fundamental goals, a clear pattern emerged, whereby the remediation-oriented approach taken by anti-trafficking and worker rights groups aimed to expose the broad reality and complexity of labour risks and abuses related to exploitative recruitment, forced labour, and human trafficking. By contrast, due diligence tools aiming to collect information from workers to provide to businesses and others for risk-management purposes, often purposefully avoided soliciting reports of serious issues, due to the risks of receiving such data and/or a lack of intention and capacity to manage such serious labour issues. All of the firms in this category (all in the sample are for-profit businesses) reported collecting information only on issues that their business clients are

\footnotetext{
${ }^{10}$ Interview with representative of a global labour rights organisation based in Bangladesh (February 2019).

${ }^{11}$ Interview with representative of a global labour rights organisation based in Bangladesh (February 2019) and interview with a trade union representative in Bangladesh (February 2019).
} 
prepared to respond to, which is logical from a risk-management perspective, but at the same time concerning in the same way that false positives from ineffective social audits are concerning. Only some firms in the due diligence category engage the supplier (employer); most are commissioned by global buyers typically for the purpose of informing due diligence, with questions shaped by the buyer.

Two main reasons emerged regarding why due diligence tools do not necessarily aim to uncover the most serious labour abuses and risks, and instead may sometimes be designed to skirt serious labour issues. First, tech providers reported not having the capacity or interest to run the case-management systems that would be required if serious labour abuses were being regularly reported into their systems, pointing out that it would require having people on the staff to do case management or to handle real labour abuses, or it would mean running referral systems and being a part of local referral networks, which these businesses did not express any interest in. As one due diligence technology developer said:

We don't want to emphasize grievance mechanisms. We don't want individual cases, and we don't want to direct workers to assistance or do any referrals. We just want mass 'boring' data.

due diligence technology developer (interview, July 2018)

Second, due diligence tools may not necessarily aim to uncover the most serious labour abuses because the business client may not be ready or willing to deal with serious labour abuses. Again, as explained by the tech creators, Laborlink, LaborVoices, and Ulula are all tools pitched to business for the purpose of supporting their risk mitigation and due diligence. They have contracts with global buyers, typically the departments tasked with commissioning audits or sometimes responsible sourcing, and the data are typically owned by whoever pays for them, with the tech provider holding rights to aggregate and publish insights. One due diligence technology developer described themselves as 'a very easy extension of the audit methodology'. ${ }^{12}$

Each of the due diligence tools has unique ways in which they engage business, that are interesting and important to understand from the perspective of supply-chain due diligence. For example, LaborVoices engages only global buyers, and solicits feedback from workers through an automated survey administered by way of a toll-free number that workers can call. This is done after LaborVoices teams go into worker community living areas to recruit respondents. From this, they are able to collect information through an electronically run survey tool administered via telephone, on a range of different suppliers, to create industry benchmarks to share with global buyers to inform sourcing decisions. There is often little or no relationship with the

\footnotetext{
${ }^{12}$ Due diligence technology developer (interview, October 2018).
} 
suppliers (employers), and, in fact, they explain that suppliers often have no idea when data collection exercises are being undertaken. Laborlink, on the other hand, has relationships with both global buyers and buyer associations: for example, the Responsible Business Alliance (formerly the Electronics Industry Citizenship Coalition) contracts Laborlink to collect information from workers in supplier sites who are aware of the data collection exercise as well as of other associated audits associated with ELEVATE, the auditing firm that owns Laborlink. ELEVATE is also able to offer training and consulting to enable suppliers to improve, based on audit and Laborlink findings. Ulula collects data and shares them with clients in a way that both the suppliers and the brands get access to the data in real time, though with different views, with brands but not suppliers able to see aggregates of multiple suppliers.

Still, whether the primary relationship is with buyers alone or also with suppliers, business clients dictate what they want to learn or get out of the due-diligence-oriented tools, and, as one due diligence technology developer explained:

We are often not finding cases of modern slavery. Suppliers are not going to put us in front of the hardest problems ... information goes to suppliers/brands and it's up to them what they do.

due diligence technology developer (interview, October 2018)

One field-based consultant managing the roll-out of one of the due diligence worker feedback tools corroborated this view from his experience on the ground. He explained how the data collected from workers are limited and skewed, as they are collected in only one day and avoid major areas with serious issues - for example, living and housing conditions, even though the living conditions of the workers are known to be very bad, with the housing in some cases being over-populated warehouses with little ventilation.

In comparison, remediation-oriented tools in the study - specifically, the RADAR Database, Contratados, Golden Dreams, Muglan, Shuvayatra, and Phulki's Amader Kotha helpline - are all technologies that fit into a larger suite of tools and programming that all work directly with workers - large numbers of workers across a range of industries, geographies, and migration flows - and aim to empower and educate workers and jobseekers regarding the realities of the risks and patterns of labour exploitation, and how to avoid it. The technologies were created to scale up the number of jobseekers and workers who could be supported in understanding the risks and opportunities they faced in labour migration, and how they could get help. These organisations are locally based (though they can be international) non-profit operations, staffed with lawyers, paralegals, counsellors, and case-management officers among others, in order to be able to provide quality legal and policy analysis and direct services to jobseekers and workers. Some also worked closely with other local partners for reach and effectiveness. 
When these staff were interviewed in the field, they clearly saw the technology tools created by their organisations as an extension of their ongoing 'offline' work to reach, educate, empower, and assist jobseekers and workers. ProDesc's database is an extension of their ongoing legal aid programme; Contratados is an extension of Centro de los Derechos del Migrante's ongoing work to reduce labour exploitation from Mexico to the United States, working at source and destination, and Golden Dreams is similar for the Issara Institute in Southeast Asia; Shuvayatra is an extension of the Asia Foundation's support to the source-side safe migration programming of their sub-grantees; Muglan serves as an extension of a Nepalese migrant worker help desk in destination countries; and the Amader Kotha helpline builds on Phulki's decades-old engagement in providing childcare to garment factory workers in Bangladesh. They are all connected to robust offline programmes and networks. Administrators aim to make some data public and accessible to workers, in the cases of Contratados, Golden Dreams, Muglan, and Shuvayatra. In the case of the Issara Institute's technology platform, Golden Dreams, data are aggregated with other worker voice channel data (multilingual migrant worker hotline, chat applications such as Viber and Line, and Facebook Messenger), and multi-purposed to drive due diligence and remedial actions by business, through contractual relationships between the Issara Institute and seventeen global brands and retailers sourcing from Southeast Asia. However, other remediation-oriented tools have little or no relationship to business as a leverage point for improving workers' lives, though ProDesc is exploring how their confidential legal database can be used for US lawyers to build cases against employers of guest workers with $\mathrm{H} 2 \mathrm{~A}$ and $\mathrm{H} 2 \mathrm{~B}$ visas. Given the nature of chain migration between the United States and Mexico, and the cooperation between employers on both sides of the border, ProDesc's secure database has been able to launch cases of joint liability, and establish legal precedent in a handful of key cases.

Caravan Studios' Worker Connect is an interesting and unique case study in that it was funded by a development donor (Humanity United) for the use and benefit of a global engineering firm, $\mathrm{CH} 2 \mathrm{M}$, which did not fund the tool but whose interests and requirements drove its design, with the intention for it to be used across the construction sector in the Gulf State. The engineering firm was interested in improving labour conditions in their projects' supply chains for workers across a range of nationalities, due to problems already identified on these kinds of Gulf State construction sites. Workers use the Worker Connect app to learn about their rights and to connect with local resources in the Gulf. It is a completely anonymous app, and workers can use their own language to report issues they experience to the project management (PM) firm overseeing worker welfare conditions on their construction project. The worker welfare team that receives the reports can analyse the feedback from workers and address areas of concern with project contractors and subcontractors. It is a two-way 
engagement tool. Worker welfare professionals can engage workers directly by posting information and publishing polls to the app, with the primary purpose of gaining a better understanding of working conditions directly from workers, in order to determine where immediate action is required to improve working conditions.

Engagement of workers with the Worker Connect tool could not be verified through fieldwork, since a trip to the Gulf was not possible, and no returned workers in Nepal and Bangladesh were found who had ever used it (noting that finding such workers would be a formidable 'needle in a haystack' type of challenge). However, it can be seen that, while the power and intention driving the tool are those of business, it is clearly for remediation and not due diligence purposes. Furthermore, while business shapes the direction of development, the focus is on the worker first, and developing and maintaining the trust of workers. As the tech developers at Caravan Studios note:

This works because there is a commitment to how they [the PM firm] interact with the data they get through the tool. We are most excited about how Worker Connect has triggered conversations that wouldn't have happened otherwise ... and shaped how worker welfare departments think about worker engagement.

Caravan Studios (interview, February 2019)

Key Finding 1.2. There are significant differences in the ways that due diligence tools versus remediation-oriented tools interact with workers, which determine the richness and accuracy of the picture formed with regard to labour risks and conditions.

Who shapes the conversation: workers or business?

All tools examined in this study involve workers somehow using their mobile phone, but beyond that, there is great divergence and diversity regarding what is asked, how it is asked, and how workers are able to respond. Tools varied in their modality - from non-smartphone-based interactive voice response (IVR) to website to smartphone-based Android applications - based on the technical competencies of the users, as well as the goals and objectives of the technology creator (Farbenblum et al. 2018). Following on from this, there were important differences in what was being asked of workers, and how. The due diligence tools examined in this study tended to ask a limited set of questions with forced-choice responses, based on due diligence requirements of the business client and/or other 'big data' aspirations-for example, Laborlink described the ability to run a twelve-question survey with thousands of workers in different workplaces, in a data collection exercise piggybacked on scheduled audits. This massive scale survey has allowed Laborlink to amass significant data from more than one million workers to benchmark and report back to business (Laborlink n.d.). Often there were ways in which to allow workers to add additional 
comments, but the structures and tone were very much determined by the business client and the technology provider.

When questions for worker feedback technology tools do not derive from any preliminary survey of, or programme interventions with, workers to learn what issues are most important to them, the technology tools may or may not capture the most pressing labour risks and abuses, for two reasons: first, because they may not have asked the right questions; and, second, asking what is perceived by workers to be less relevant questions can lead workers to conclude that the exercise is not important or relevant to their lives, and therefore not worth investing effort and making a leap of faith to divulge more sensitive truths. The result of such data collection exercises, then, is that business clients are sure to receive a suite of information that covers all of their required reporting areas, but the data may be incomplete, inaccurate, and/or overly positive. As one global seafood buyer explained:

We are not using these audit-plus [due-diligence-focused] tools because when they present reports to us, we don't have a sense of where those issues came from - did they come from the supplier? Did they come from the tech company? But we know they don't come from the workers.

global buyer (interview, January 2019)

But as one due diligence technology firm's founder explained:

We never promise to tell the truth-we promise to tell a truth. We aim to contribute to the body of knowledge but do not feel the need to cross-check and verify the data ... we just describe how we got it.

due diligence technology developer (interview, June 2018)

In response to this general sentiment, however, one development donor reflected:

These tools are just enabling and accelerating the scale-up of more bad audit data. development donor in the worker rights/worker voice space

(personal communication, January 2019)

Do workers have to be paid to get them to use the technology tool?

The degree to which the technology tool reflects the priorities of workers and leads to responsiveness to worker risks and concerns, strongly shapes workers' level of trust with the tool, and whether workers value the tool or not. This, in turn, shapes the quality and quantity of information gained from workers with regard to labour conditions. It is noteworthy that all due diligence tools included in this study paid monetary incentives to drive up worker response rates, while no remediation-oriented tools had to pay incentives to drive feedback or general worker contributions to or use of their platforms. The most common remuneration paid to workers for their use of due diligence tools was receipt of phone credit, which has been documented as not 
always being paid as promised (Farbenblum et al. 2018: 7).

Our field team interrogated the perceived value of remediation-oriented tools to workers, and why workers use them without being remunerated, gaining useful insights from former migrant workers in source countries engaged in outreach and awareness raising to prospective migrants - specifically, Golden Dreams Ambassadors in Myanmar, supported through ongoing Issara Institute programming, and Migrant Defense Committee (Comité) members, supported through the ongoing programming of the CDM. One former migrant worker and Golden Dreams Ambassador in Myanmar explained:

More and more job seekers are using Golden Dreams because it is free and has all the information they need. For job seekers, they look for recruitment agencies' information. If an offline option were available, the number of users would definitely increase even more, because many people who cannot afford to or want to pay for data will also start using it.

former migrant worker and Golden Dreams Ambassador (interview, January 2019)

Along similar lines, a Comité member in rural Mexico explained how the Contratados website is a tool that gets people enough information for them to have a face-to-face meeting with Comité members or call CDM. He explained:

Comité members encourage people to write reviews, but most people only do research. Sometimes people are afraid to write a bad review, even if they are anonymous. Sometimes the recruiter can still know who it is, especially if it was only a small group of workers. But, sometimes, it is helpful in unexpected ways-like when a recruiter sees his own name on the website, he knows he is being watched and monitored.

former migrant worker and Comité member (interview, June 2018)

Connected to supply chains but not to corporate actors

While the majority of remediation-oriented worker feedback tools contain rich, accurate depictions of the realities of labour risks and abuses, because the formats are blog-type discussion threads and Yelp-like information exchange platforms that allow workers to raise the issues and points most important to them, there are serious challenges from the perspective of eliminating modern slavery from supply chains. In short, for the majority of remediation-oriented tools, there are no clear linkages to business to inform due diligence or remediation actions of these nuanced, workerverified pictures of labour and recruitment conditions. Rich information is presented about recruitment and labour conditions in specific sectors and visa regimes-for example, the Contratados platform contains rich information about labour conditions in US food processing sectors in specific states, through the H2B visa, as well as in agriculture through the $\mathrm{H} 2 \mathrm{~A}$ visa - even down to the name of the employer. There have been a number of success stories where cases and information posted to 
Contratados have led to legal cases that were won in the US courts by CDM, as well as learning and worker-led advocacy that have led to some legal reforms (CDM 2015). However, few efforts have been made to date to link these suppliers to global buyers or retailers which may be interested in improving labour conditions in their supplier base, since this is outside CDM's theory of change and institutional mandate, and no other partner has yet identified and filled this gap.

Three notable exceptions include Issara Institute's reporting to its global buyer partners and helping suppliers on the ground to implement remediation and more responsible sourcing based on worker feedback; Phulki's Amader Kotha hotline which negotiates remediation based on worker feedback through telephone calls with the employers; and Caravan Studios' Worker Connect, whose main design objective was to link workers and their issues with the construction management (CM) firm subcontracting to their employers, for the purpose of improving working conditions. Both the Issara Institute and Phulki first contact employers to try to drive remediation based on worker feedback, and then escalate the case to relevant global buyers for visibility and action if required. Phulki does not meet workers or employers in this process, conducting all phases of investigation and negotiation through telephone calls, while the Issara Institute's team meets workers and employers to investigate, mediate, and attempt to strengthen connections between workers and employers.

One interesting distinction with Caravan Studios' approach to remediation is that Worker Connect does not collect and store personal identifying information from workers, unlike the Issara Institute, which collects and securely stores personal identifying information from workers within its case-management systems so that individual remediation cases can be supported by its team. This is reflective of the institutional structures and mandates of the two non-profits: Issara Institute's team is locally based and includes case managers and psychosocial counsellors of the same nationality as the workers, whereas Caravan Studios' San-Francisco-based experts focus on technology development, programme management, and partnership, and not case management. However, anonymous grievances viewed by the PM firm can be aggregated and responded to with the Worker Connect tool and assigned to trained worker welfare managers.

In the case of the other remediation-oriented technology tools examined in this research, however, there were no linkages between the rich information they contained about source-side and destination-side risks, and risk in supply chains being managed by business. The main channels to direct remediation and assistance were essentially linkages to legal aid (in the case of Contratados and the RADAR Database), or rescue and advice (in the case of Muglan). Intervention by local unions through the International Trade Union Confederation's Recruitment Monitor in response to migrant abuses in Malaysia was found to happen rarely due to reported anti-foreign 
migrant sentiment and sparse resources, as perceived and reported by foreign migrant workers who were only able to receive assistance from their own national union or from grassroots worker rights and faith-based organisations. Shuvayatra's referral list of telephone numbers of embassies and civil society organisations abroad also seemed fairly comprehensive yet distant to actual remediation, based on a brief survey of migrant usage of Shuvayatra in the destination country of Malaysia. Its main strength, following its 'origin story', is as a source-side safe migration tool at this point, with few destination-based Nepalese organisations actively promoting or being aware of the tool among the migrant communities they support.

\section{Effectiveness and accuracy of the technology tools at addressing human trafficking and forced labour}

Key finding 2.1. Non-profit-run remediation-oriented technology tools commit to making a direct impact on the lives of workers, as required by development donors and non-profit missions themselves, but business-run due diligence tools do not; their business contracts generally commit them to data outputs and deliverables alone.

\section{Commitment to deliverables versus commitment to impact}

A key challenge faced by the research team in assessing the effectiveness of tools at addressing human trafficking and forced labour was that only some of the tools- the remediation-focussed tools - explicitly and directly aimed to make an impact on workers, in a proximate manner. The due diligence tools generally aimed to produce deliverables supporting corporate due diligence processes which could theoretically lead to improvements in addressing human trafficking and forced labour-however, the due diligence technology tools clearly assumed no responsibility themselves for any changes taking place. Eventually the research team determined that this was a key finding in and of itself. The goals and objectives of each of the tools, as articulated by their chief executive officers or leadership and anonymised, are summarised in Table 3.

From the perspective of theories of change, the remediation-oriented tools had commitments to a theory of change down to the level of impacting on workers. This is not surprising since non-profit organisations are typically held to an impact framework by their donors and board of directors. Some of the measurable indicators of impact that remediation-oriented technology tools worked toward included 'jobseekers choose safer jobs and migration channels', 'workers access remediation from their employer', 'a critical mass of workers is built to drive remediation', 'workers access legal aid and justice', and 'improvements in how worker welfare departments think about and carry out worker engagement'. 
Table 3. Goals and objectives of a selection of different worker feedback tools, as articulated by their creators.

\begin{tabular}{ll}
\hline Due diligence-oriented tools & Remediation-oriented tools \\
\hline $\begin{array}{l}\text { 'First, create more timely, credible data about } \\
\text { conditions and impact, and secondly create an }\end{array}$ & 'Our initial focus was recruitment transparency, \\
infrastructure for data-sharing where workers can & wanted to help better information to be shared in \\
get feedback on conditions they reported on. The & real time and offer assistance with remediation and \\
buyer gets better data, and the employer gets a & legal advice.' \\
better sense of working performance in the factory. & 'We wanted to build a platform for workers to be \\
But we are only providing an infrastructure for lots & able to exchange the vast amount of information \\
of people to use, and it's incumbent on stakeholders & they had about labour risks and opportunities; \\
to decide what to do with the data.' & all of us NGOs combined will only ever know a \\
'Collect more timely, reliable, and actionable data & fraction of what workers know. Then from this we \\
that companies can use to drive change. And, & wanted to help connect issues and demands with \\
information that workers receive can be used to & support and remediation-from employers and \\
advocate for change on their own behalf in their & business, from local NGOs and service providers, or \\
own workplace.' & even from government.' \\
'Our goal is to help buyers make better business & 'Give workers valuable information on what they \\
decisions, to know who is a good bet from a supplier & want to know about what affects them on a day to \\
perspective ... and to drive competition among & day basis, and get workers to share information \\
suppliers by benchmarking them against their peers. & to help their lot as a greater good, rather than to \\
If you want factories to get better, or buyers, they & expect their own individual issues to be addressed \\
have to compete. They just don't do it without open & ... the project manager is ready to respond from \\
data.' & a worker welfare perspective, and the contractors \\
& are looking at it from an HR [human resources] \\
& perspective.'
\end{tabular}

In contrast, the due diligence tools included in the study, all run by for-profit firms with very different clients and business models, expressed commitments down to the level of deliverables for their business clients. Similarly, this also should not be surprising, since business service providers are typically held to contract deliverables by their business clients. For the due-diligence-oriented worker feedback tools, then, this means that there is no real commitment to action based on the data on the part of the tech service provider: as several tech service providers explained, 'it's up to the business client what they do or not do with the data'. ${ }^{13}$

\section{Tech in a vacuum}

While the due-diligence-oriented worker feedback tools generally seek to gather data only on what the businesses are prepared to deal with, and ultimately those businesses may or may not act on what they learn, it was explained that there may be some other secondary pathways to change. For example, a due diligence tech creator explained how their tool has the potential to lower barriers to workers reporting exploitation

${ }^{13}$ Due diligence technology developer interview (October 2018). 
and getting support. It was further explained how these cases are supported by some anecdotal data, but the tech firms themselves are not able to consistently collect the data required to affirm larger patterns of such successes. However, a representative from a global human rights organisation familiar with these technologies and the real situation of migrant worker cautions:

There is a flawed logic here that expects migrant workers to step up and claim the rights they don't have. That's just not possible in so many cases. These [due diligence] technologies are not embedded in a system of accountability ... they are just data gathering tools-it's tech in a vacuum if not a part of a sound ground game with safeguards, trust, feedback, and engagement.

representative of international human rights organisation (interview, July 2018)

The partnership of Laborlink technology, Phulki's locally based Amader Kotha helpline, and technical support and oversight by the Cahn Group within the structure of the Bangladesh Alliance, is a strong example of linking worker feedback to a system of accountability through partnership between three groups with different strengths that allowed data collection to be paired with remediation, escalation, and accountability.

In summary, due diligence tools pose some enticing theoretical pathways to real change, but they do not see themselves as being responsible for whether or not those changes take place; because of this, they lack data regarding impact on workers lives because directly achieving and measuring such data was never their main priority. Furthermore, their assumptions of pathways to impact may be flawed in their assumptions of the power of vulnerable populations to claim their rights in situations of labour exploitation.

\section{Unethical burdens from due diligence worker feedback tools?}

From an ethics and human rights perspective, the lack of guarantees around the outcomes for worker-sourced due diligence data leads one to question: Is it ethical to collect sensitive data from vulnerable populations but not take responsibility for how it is used? Or, should there be some sort of 'risk-benefit' analysis, similar in spirit to the institutional review board (IRB) process for medical and social science research with human subjects? This question is especially pertinent because there is a cost to workers of employing these due diligence tools. Even if it is only the time a worker spends on completing a survey, using these tools often carries some cost for the workers. In some instances, it may require the worker to share personally identifiable information (PII) or even put him/herself at risk of retaliation, especially if there is no locally based presence or partner on the ground assuming responsibility for providing safeguards against reprisals against workers reporting sensitive information, or of 
driving improvements in working conditions. While the security of respondents' PII seems to have been well considered by all of the technology tools studied in this research, and also examined in detail by other scholars (Farbenblum et al. 2018), the physical security of respondents in their workplaces and communities appears to have been under-considered in the case of the due diligence tools included in the survey, which is particularly concerning, since many of these tools are deployed on the ground in developing-world countries with varying levels of security and rule of law, often with small field teams and little or no partnership with local worker-protection groups.

One developer of a due-diligence-oriented tool explained that the fact that its large-scale quantitative survey procedure posed only those questions that an employer was interested in asking inherently protected workers from sharing potentially endangering information. Offering only a limited range of fixed responses (yes, no, maybe; or rank on a scale of 1 to 5) also, they claimed, protected workers from identification. Another due diligence tech provider noted:

Retaliation exists in the workplace ... people are always being retaliated against so it's hard to say if any of it is related to use of our platform. We don't think we've ever had an individual retaliated against.

due diligence technology developer (interview, October 2018)

Another noted, 'If there are security issues, you can make that a part of the data ...' ${ }^{14}$ going on to explain how such incidents can be noted as a data element 'red flag' for due diligence - but expressing no concern about or interest in remediation or action to protect the respondent being retaliated against.

While due-diligence-oriented tech providers articulated a perceived low risk of (or low interest in) retaliation against worker respondents, remediation-oriented tech providers recounted numerous security issues that their teams and workers had faced over the years when working on labour-abuse cases. For example, with in-depth experiences and insights into the risks faced by cheated jobseekers and workers, ProDesc specially designed its RADAR database to collect highly detailed, personal, and sensitive information in order to build legal cases, and privacy is safeguarded by ensuring that only one US attorney has access to the database for the sole purpose of building a legal case. CDM wipes Contratados' IP addresses and runs security audits regularly, and forces anonymity among users to enhance security. Golden Dreams' creator, the Issara Institute, initiated a Business and Human Rights division dedicated to working with local employers and recruiters to ensure worker safety from retribution and to pursue remediation, and an Outreach and Empowerment division to provide ongoing direct support to workers. This relationship building appears to be working,

\footnotetext{
${ }^{14}$ Due diligence technology developer interview (July 2018).
} 
from the standpoint of both safeguards and impact. For instance, a Thai-owned garment factory said that they call Issara's Business and Human Rights team to discuss and brainstorm options to address worker grievances collected from the Issara Outreach and Empowerment team and the factory's eleven-person worker committee, rather than terminate or punish a worker who files a complaint, or seek out retribution for a 'negative' rating that is posted about the business on Golden Dreams. ${ }^{15}$

The evidence overall from this study leads us to conclude that a considerable amount of planning, structures, resources, and funds may need to be dedicated to eliminating any retribution for using worker feedback tools, and to remediation of reported abuse; furthermore, safeguards for workers using technology-enabled worker feedback tools have to go well beyond the security of personally identifying information and data, and actually ensure the physical security of participating workers, on the ground, as well.

Key Finding 2.2. Companies acknowledge the need to go beyond audit to really identify and remediate labour exploitation, but see few options to do so, so they default back to audit-compliance approaches and supplier self-reports.

Global buyer companies have different commitments, attitudes, and risk appetites with regard to wanting to understand and address labour risks in their supply chains. Companies with more progressive responsible sourcing requirements openly and publicly acknowledge the need to go beyond the first tier in addressing and remediating labour issues, and have said that traditional audit-compliance approaches do not satisfactorily identify or resolve labour risks. Generally, of the global buyers interviewed in this study, many were quick to recognise the value of empowered worker-centric solutions that go beyond audit, but it was repeatedly noted that these are limited in terms of geographic or industry coverage and availability around the world. Several respondents expressed a lack of in-house capacity to expertly assess and devise solutions for complex labour risks across their extended supply chains, but with a perceived dearth of tools and locally based partners to collaborate with, there is a default back to reliance on audits and supplier self-reports regarding worker well-being.

The majority of business respondents reported an openness to emerging alternatives -if they were 'affordable' and 'scalable.' These terms may mean different things to different people, but at the core suggest challenges with limited budgets to cover labour risk across global supply chains and a desire to have partners, programmes, and tools which are common across their supply chain, rather than a patchwork of actors and approaches.

\footnotetext{
${ }^{15}$ Interview with Thai factory human resources director (July 2018).
} 
At first glance, a replicable technology 'solution' would seem the most promising answer, but taking a 'cookie cutter approach' to deploying tools may not be appropriate for each locality, and may not be a good idea if the data do not accurately reflect true labour risks and conditions, recalling the concern of a previously quoted donor that we may then be just '... enabling and accelerating the scale-up of more bad audit data ${ }^{16}$ If a business is going to rely on an audit-compliance approach, then partnering with an on-the-ground organisation that has earned the trust of workers and can deploy worker voice and safeguards well would significantly reduce risk and could improve worker well-being. These approaches can be scalable too, especially if they integrate with large migration corridors and worker flows, which social audits do not. For example, remediation-oriented tools such as Contratados tap into updated, worker-validated information on risks and opportunities within the entire Mexico-toUnited States migratory flow, into a range of industries. That data just have not yet been linked up with due diligence and remediation efforts by corporations.

\section{CONCLUSION AND RECOMMENDATIONS}

In the real world - the worlds of both international development as well as ethical trade - there are legitimate resource limitations. Donors to anti-human trafficking and forced labour programmes must navigate myriad objectives in order to determine their investment in certain tools and programmes, and businesses will invest in and adopt only so many tools to help solve their responsible sourcing issues. In deciding whether or how to use or support the development or expansion of a worker data-sourcing technology tool, we propose the following policy and programming recommendations to be considered by policy makers, donors, investors, and technology developers:

1. Ensure that worker voice technology tools are making worker lives better. Require a commitment to worker safeguards and to remediation of labour risks and abuses found through worker feedback technologies, where at least one party clearly assumes responsibility for any and all impacts of the technology tool on workers. Soliciting sensitive digital data from workers and other vulnerable populations creates ethical risks and burdens. These can only be offset through a commitment, from some actor(s) privy to these sensitive data, to respond and protect workers. Ensure clarity regarding which actors are committed to safeguards for workers, and which are committed to action to remediate risks and

\footnotetext{
${ }^{16}$ Development donor in the worker rights/worker voice space (personal communication, January 2019).
} 
issues found. The production of worker feedback-based due diligence reporting that lacks a responsible party to protect and respond to harmed workers is ethically unacceptable, and unnecessary given all the current technologies and potential partnerships available in many parts of the world.

Donors and businesses, as well as technology developers themselves, should consider: Who benefits from this tool, and how do they benefit? Do workers honestly and directly benefit from this tool? Are workers demanding this technology, or is it being imposed upon them? Might they be harmed by it, and if so, who is taking responsibility for mitigating these risks and ensuring no harm is done? What are all the pathways and probabilities of achieving positive impacts, negative impacts, or no impacts?

Consider what alterations to the technology tool, its design, or the manner in which it is deployed on the ground and within supply chains could help it to increase its positive impacts on worker lives, and decrease its negative impacts (or likelihood of there being no impact). Consider how different partnerships or more inclusive partnership structures - with buyers, suppliers, local development partners, trade unions, workers, or other key stakeholders-could increase the positive impacts and decrease the possible negative impacts of a proposed technology tool.

2. Commit to and scale-up technologies and programmes that can answer to business needs for due diligence and remediation (and more ethical supply chains more generally) simultaneously. With new opportunities to receive business intelligence directly from workers at scale, and increased accountability and transparency demanded of global procurement teams and supply chains, more direct pathways from due diligence to remediation become possible - if the corporate commitment to remediation is confirmed. With this corporate commitment to remediation and decent working conditions, the problem of 'tech in a vacuum' can be avoided - essentially, that problematic assumption that technology can help vulnerable populations by providing a communications channel to claim their rights, when in reality such channels achieve little without a commitment to respond to workers' claims.

When worker-empowering organisations and tools can be supported to build new channels for due diligence as well as remediation, businesses would be improving their human rights footprint as well as developing their access to a richer, more reliable, picture of labour risks in their supply chain.

3. Design the technology and the ecosystem in which it is deployed with a commitment to accurately identify and address serious labour risks and abuses. If aiming to develop a tool whose stated aim is to help reduce forced labour, human trafficking, and/or modern-day slavery, then do not avoid collecting 
data on the most serious labour risks and issues. If the currently conceived ecosystem lacks the capacity or will to manage serious labour cases and security risks, then it is essential to build out the ecosystem to involve a wider range of partners, including some that are well positioned to manage serious labour cases and security risks. Despite the incentives to pose large claims about impacts to combating modern-day slavery, always be clear about the solution's intentions and limitations.

4. Design the technology, and the ecosystem in which it is deployed, to allow workers to lead and shape the conversation-to address information and power asymmetries contributing to forced labour and human trafficking, as well as to improve the quality and quantity of information collected. The most pressing labour risks and abuses and their underlying causes are most likely to surface when technology tool formats and interfaces are: first, designed for the specific user population; and, second, designed in a way that allows workers to shape the conversation by being able to safely and freely raise whatever they perceive to be most important - as opposed to just answering a battery of questions that businesses want answered. Businesses, donors and investors, and technology developers are all strongly encouraged to embrace the fact that the degree to which the technology tool reflects the priorities and concerns of workers strongly shapes workers' level of trust with the tool, how they value it, and the quality and quantity of accurate information gained from workers with regard to labour conditions - and consider what this means for both due diligence and remediation of labour abuses in supply chains.

5. Ensure that technological interventions do not displace other modes of worker organising. Finally, while this paper has discussed the promises, opportunities, and challenges posed by recent tech tools to address worker abuse, it has yet to highlight one key dilemma that emerged during the research: do new technological approaches to capturing 'worker voice' displace existing forms of worker organising? Do calls for funding for technology-driven projects divert funding away from other anti-trafficking interventions around direct service or advocacy? Understandably, the rise in interest for technological interventions stems from their promise to deliver widely impactful and large data sets about trafficking. However, these are often enormously costly - and as we have found, may have some unintended negative consequences on worker power and security that are just coming to light. Before considering further entrenchment in what Musto and Boyd (2014) have described as a fetishation of the technology-trafficking nexus, donors might simply question how their higher-level objectives and ethical standards would best be met if at least some portion of these funding streams were awarded to labour-rights groups and 
worker communities that have been advocating for workers' rights for decades-often with limited funding, corporate leverage, or global recognition.

Acknowledgements: This research was funded by a grant from the British Academy programme 'Tackling Slavery, Human Trafficking and Child Labour in Modern Business'. The authors also wish to thank co-investigator Aaron Halegua (New York University Law) and Issara Institute researchers Jarrett Basedow, Ohnmar Ei Ei Chaw, Sanjeev Dasgupta, Sandar Linn, and Ana Maria Soto for their contributions to fieldwork and drafting.

\section{REFERENCES}

Australian Modern Slavery Bill (2018). https://www.aph.gov.au/Parliamentary_Business/Bills_ Legislation/Bills_Search_Results/Result?bId=r6148

Barrett, Paul M. Baumann-Pauly, Dorothée \& Gu, April (2018), 'Five Years After Rana Plaza: The Way Forward', NYU Stern Center for Business and Human Rights.

https://static1.squarespace.com/static/547df270e4b0ba184dfc490e/t/5ac9514eaa4a998f3f30ae13/ 1523143088805/NYU+Bangladesh+Rana+Plaza+Report.pdf

Brabant, S. \& Savourey, E. (2017), 'A Closer Look at the Penalties Faced by Companies'. https://www.business-humanrights.org/sites/default/files/documents/French $\% 20$ Corporate $\% 20$ Duty $\% 20$ of $\% 20$ Vigilance $\% 20$ Law $\% 20-\%$ 20Penalties $\% 20-\% 20$ Int $\% 25271 \% 20$ Rev.Compl_.\%20 $\% 26 \% 20$ Bus. $\% 20$ Ethics_.pdf

California Transparency in Supply Chains Act of 2010 (2010), Senate Bill 657. http://www.state.gov/documents/organization/164934.pdf

CDM (2011), 'Monitoring International Labour Recruitment: A Cross-visa Exploration of Regulatory Challenges', Centro de los Derechos del Migrante.

https://cdmigrante.org/wp-content/uploads/2018/02/Monitoring_International_Recruitment.pdf

CDM (2015), 'Ten Years of Impact: 2005-2015', Centro de los Derechos del Migrante. https://cdmigrante.org/wp-content/uploads/2018/01/Impact-Report-2015_FINAL.pdf

Explanatory Notes to Modern Slavery Act 2015 (Transparency in Supply Chains) Regulations 2015, Sections 7.1-7.2. http://www.legislation.gov.uk/ukpga/2015/30/pdfs/ukpgaen_20150030_en.pdf

Farbenblum, Bassina, Berg, Laurie \& Kintominas, Angela (2018), 'Transformative Technology for Migrant Workers: Opportunities, Challenges, and Risks', Open Society Foundations, New York. https://www.opensocietyfoundations.org/sites/default/files/transformative-technology-formigrant-workers-20181107.pdf

Laborlink (no date), 'With Just a Cell Phone, Factory Workers are Being Heard', Laborlink, Good World Solutions. http://goodworldsolutions.org/laborlink/

Loi relative au devoir de vigilance des sociétés mères et des entreprises donneuses d'ordre (2017). https://www.legifrance.gouv.fr/eli/loi/2017/3/27/2017-399/jo/texte

Musto, Jennifer Lynne \& Boyd, Danah (2014). 'The Trafficking-Technology Nexus', Social Politics, 21(3): 461-83.https://doi.org/10.1093/sp/jxu018

Porter, E. (2017), 'The Danger From Low-skilled Immigrants: Not Having Them', New York Times, 8 August.

https://www.nytimes.com/2017/08/08/business/economy/immigrants-skills-economy-jobs.html 
Rende Taylor, Lisa \& Ei Ei Chaw, Ohnmar (2018), 'Driving Behaviour Change of Recruiters, Suppliers, and Job Seekers Toward Ethical Recruitment: Critical Roles of Global Buyers \& Grassroots Actor', Issara Institute, Bangkok. https://docs.wixstatic.com/ugd/5bf36e_4620b33fdea7485382683dd927a97378.pdf

Rende Taylor, Lisa \& Latonero, Mark (2018), 'Updated Guide to Ethics and Human Rights in Antihuman Trafficking: Ethical Standards and Approaches for Working with Migrant Workers and Trafficked Persons in the Digital Age', Issara Institute, Bangkok. https://docs.wixstatic.com/ugd/5bf36e_1307f698e5ec46b6b2fc7f4391bff4b6.pdf

State Department (2018a), '2018 Trafficking in Persons Report. Thailand: Tier 2', Office to Monitor and Combat Trafficking in Persons, US Department of State.

https://www.google.com/search?q=us+dos\&rlz=1C5CHFA_enGB816GB816\&oq=US+

Dos\&aqs $=$ chrome. $0.016 .6233 \mathrm{j} 1 \mathrm{j} 7 \&$ sourceid $=$ chrome\&ie $=\mathrm{UTF}-8$

State Department (2018b), '2018 Trafficking in Persons Report. Malaysia: Tier 2 Watch List', Office to Monitor and Combat Trafficking in Persons, US Department of State.

https://www.state.gov/j/tip/rls/tiprpt/countries/2018/282701.htm

Verité (2018), 'Gap Inc.'.

https://www.verite.org/wp-content/uploads/2018/08/Verite-Gap-Inc-Employing-Workers-SOVas-KPI.pdf

Yee, A. (2015), 'Two Years After Rana Plaza, Are Bangladesh’s Workers Still at Risk?', The Nation, 22 May.

https://www.thenation.com/article/two-years-after-rana-plaza-are-bangladeshs-workers-still-risk/

\section{Notes on the authors}

Lisa Rende Taylor is Founder and Executive Director of the Issara Institute, an independent non-profit organisation based in Southeast Asia and the United States tackling issues of human trafficking and forced labour in global supply chains through worker voice, technology, partnership, and innovation. Her recent publications have focussed on the topics of ethics and human rights in anti-trafficking and responsible sourcing; driving more responsible labour recruitment in global supply chains; and human trafficking and forced labour in the Thai and Indonesian fishing sectors. lisa@issarainstitute.org

Elena Shih is Assistant Professor of American Studies and Ethnic Studies at Brown University, and Faculty Fellow at the Center for the Study of Slavery and Justice, where she leads an interdisciplinary human trafficking research cluster directing project in three areas: (1) Race and modern-day abolition; (2) Policing sex worker rights; and (3) Worker voice in global supply chains. Her forthcoming book manuscript, "Manufacturing Freedom: Trafficking Rescue, Rehabilitation, and the Slave Free Good" (under advanced contract from University of California Press), is a global ethnography of state and market-based responses to trafficking in China, Thailand, and the United States. An additional co-edited volume under contract with Routledge, with Kamala Kempadoo, explores the racial politics of global anti-trafficking efforts. elena_shih@brown.edu 
To cite the article: Lisa Rende Taylor and Elena Shih (2019), 'Worker feedback technologies and combatting modern slavery in global supply chains: examining the effectiveness of remediation-oriented and due-diligence-oriented technologies in identifying and addressing forced labour and human trafficking', Journal of the British Academy, 7(s1): 131-165.

DOI https://doi.org/10.5871/jba/007s1.131

This article is licensed under a

Creative Commons Attribution-NonCommercial-NoDerivs 4.0 Unported License.

Journal of the British Academy (ISSN 2052-7217) is published by

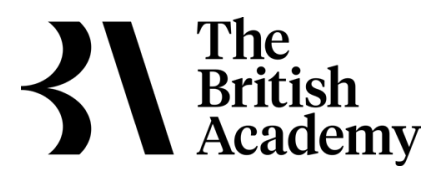

10-11 Carlton House Terrace, London, SW1Y 5AH

www.thebritishacademy.ac.uk 
